\title{
RELIGIOUS MORAL IMPERATIVE AS A GUARANTEE FOR SAVING SPIRITUALITY AND CULTURE OF COEXISTENCE
}

\author{
Bodak V. A.
}

\section{INTRODUCTION}

The problem how to harmonize relations between people, between personality and society, civilization and culture always remains relevant. In the overflowing with global social catastrophes $21^{\text {st }}$ century, they became particularly acute. Radical changes that take place, the blurring of the boundaries between the proper and the improper, the pursuit of freedom and the "escape from freedom" put a strain on modern man. Now, the situation arises where an educated person, but spiritually and morally immature, who is experiencing serious internal problems, undertakes to draw the line between good and bad, set the limits of what is allowed and not allowed, trying to establish own truth, from which makes this person suffer as well as its environment and society as a whole. All this is because spiritual values cease to be basic, and one after another various aspects of human activity fall out from religious life, threatening the fundamental religious principles on which morality is based. Such a reality is relevant to both the national and the global level, posing significant challenges for individual Churches, for culture in general and for all human civilization. We see how what is now called mass culture leads to a moral crisis of the individual, which, in turn, leads to a global crisis of civilization; there is a collapse of the human personality, a mass departure from the basic norms of morality.

Also, there is another important prerequisite that drives us to actualize the issue of religious moral imperative. We mean a sharp and most dangerous aggravation of inter-civilizational, inter-religious, inter-ethnic conflicts in the modern world.

The question arises: in a time of pluralistic philosophizing, ethical relativism and nihilism, can the general categories of good and evil serve as a benchmark for evaluating human intentions and actions and the direction of social processes? What are the prospects of cultural coexistence: a measure of tolerance and personal value orientation, which is realized in the act of moral choice and awareness of the responsibility for the consequences of its implementation?

These and other questions urge us again and again to turn to the problem of internal spiritual agents, internal imperative. "The complexity of modern life, which has been defined as a crisis of humanism," V.S. Movchan 
emphasizes, "puts humanity before the need to focus on factors that can open up the prospects for further development and eliminate the sense of approaching eschatology of history"1. It is the Christian tradition that preserves such a spiritual factor - a moral imperative that is able to nourish the mind and feelings of a person, to inspire genuine, direct communication, mutual friendship and trust. And it is very important, in our difficult time, that in the course of modern dynamic changes, the traditional that formed the basis of our spiritual world for two millennia should not be rejected.

\section{Christian moral imperative}

Relation between religion and morality in different cultural traditions has its own peculiarities, practical forms of expression and even has antinomic nature. But religion in society predominantly acts as a kind of regulator of social relations, behavior, ideas, values of people on the basis of which they act. There is no stronger regulator of moral mindset in society than the religious one. First of all, because it is impossible to put forward something as a value, a norm of behavior, a norm of morality to refer to a higher authority other than God, who commanded the notion of values, proper actions and thoughts. His authority is underpinned by the notion of sin, improper, unlawful, punishment that can be inflicted on a person who violates moral standards. The argumentation for the consciousness of a person within the religious description of the world has the force of law, which cannot be compared with any social law. Social laws, justice, morality cover only the external actions of man and do not create a moral imperative in the exact meaning of the word. This is an external coercion that regulates relations in society. However, the formation of an internal imperative is not connected with external compulsion but with the tradition and customs learned in culture. Religion in any culture remains the basis of spiritual tradition, influencing the perception of values and norms of behavior.

It is necessary to be aware of the significant difference between a religious moral imperative and a secular ethic, first of all, by its worldview prenises that emerge from the picture of the world, and therefore by a way of substantiating the permissible and the impermissible, the valuable and the pernicious, since there is a different understanding of the truth, laws and foundations of the world. In his work "Unfading Light" S. Bulgakov quite clearly illustrates that religious ideas and images are not only a projection of human essence, the beginnings of reason and morality, but also speak of the existence of a higher, superhuman law, a higher mind whose ways are unknown to him $^{2}$. Secular

\footnotetext{
${ }^{1}$ Мовчан В.С. Історія і теорія етики. - Дрогобич.: Коло, 2003. - С. 5.

${ }^{2}$ Булгаков С. Свет невечерний. Созерцания и умозрения. - URL: https://azbyka.ru/otechnik/ 6/svet-nevechernij-sozertsanija-i-umozrenija/
} 
ethics do not need to justify their norms of appeal to the authority of God. Therefore, the norms of secular ethics are different, appear as established by people, cannot be declared, which makes their violation easier, and moral subjectivism in the formation of internal moral law is almost inevitable.

Religious moral norms are transformed into an internal imperative, if a man voluntarily accepts establishing his relationship with God as the fundamental value, recognizes the Church tenet of salvation of the soul and punishment for sins. The internal imperative is different from the external compulsion. Its conceptual basis is the basic principle of Christian religion. The behavior of a religious person is best controlled by his own faith, his perceptions of good and evil, of the righteousness and sinfulness given to him by God, and in a very specific list of sins, blessings and commandments.

For the individual, the role of the religious moral imperative may lie not only in providing moral, semantic orientations, but above all in providing a method of overcoming existential problems caused primarily by self-absorption. Religious ceremonies and rituals significantly reduce one's self-absorption (including confession, repentance). Eliminating selfabsorption means for a person to optimize the activity of his psychic structure.

The Mosaic commandments put purely religious guidance at the starting point. It is only after them that they speak of the demands and prohibitions of a moral character which, at first glance, have no logical and essential connection with the belief in the supernatural and retain their meaning beyond the religious system. The same is the situation in Christianity. (See Mt 22: 36-40). The first commandment and greatest virtue for the believer is: "You shall love the LORD your God with all your heart, with all your soul, and with all your mind". This commandment reflects the central value of religious consciousness - to love the Almighty more than yourself. Following the significance of the commandment -"love your neighbor as yourself," "love your enemies, bless those who curse you", "do not judge, so that you may not be judged." In fact, in addition to the high moral content, there is a very expedient way of directing a person's mental energy not at destruction but at creation, not to condemn someone, but instead to work on oneself. Otherwise, the units of attention are diverted to the negative, which becomes the focus of the arbitrary attention of the person. This saves the man both energy and creativity, because at the same time arbitrary attention cannot be directed at several objects at once. From this point of view, the moral imperative of religious culture is not only regulative but also expedient in terms of energy expenditure.

The moral teaching of Christianity is on the path of rethinking and deepening Old Testament morality. Rejecting the accusations of breaking the moral law, Christ says, "Do not think that I came to destroy the Law or the Prophets. I did not come to destroy but to fulfill" (See Mt 5: 17). 
Nevertheless, the commandments of Jesus Christ reject the literal observance of Old Testament morality. Christ focuses not on the letter of the law but on its spirit filling it with a new meaning. The commandment "You shall not murder" is transformed into the commandment "whoever is angry with his brother without a cause shall be in danger of the judgment." Anger is not murder, but unjust anger is condemned to the same extent as murder. The commandment "You shall not swear falsely, but shall perform your oaths to the Lord" turns into the commandment "do not swear at all: neither by heaven, for it is Gods throne; nor by the earth, for it is His footstool..." The commandment "An eye for an eye and a tooth for a tooth." turns into the commandment "not to resist an evil person. But whoever slaps you on your right cheek, turn the other to him also." The commandment "You shall love your neighbor an hate your enemy" also takes on a new meaning: "love your enemies, bless those who curse you, do good to those who hate you, and pray for those who spitefully use you and persecute you" (Matt; 5: 22, 24, 28, 32, 34, 39.44).

The love of God, the love of men is the main Christian virtue. Long before Kant, Jesus Christ proclaims the "golden rule of morality": "Therefore, whatever you want men to do to you, do also to them" (Mt 7:12). Not only love for loved ones, but also for enemies, for those who hate you - this is a way by which one can approach God. "For if you love those who love you, what reward have you? Do not even the tax collectors do the same?" (Matthew; 5:46) Thanks to the love of enemies, one acquires moral perfection, ascends to a new moral height, and thus approaches God. Of course, one cannot attain the perfection of divine love, one cannot be like God, but one must strive for that ideal.

Throughout his life, Jesus Christ was an example of Christian love, humility, and submission to the will of God. Even in the approach of a dreadful death - the crucifixion on the cross - he follows in the way outlined above: "nevertheless not My will, but Yours, be done" (Luke; 22: 42). Man must unconditionally accept the will of God, not replace him with himself trying not to make his own decisions. Humility, obedience is the ability to accept any life situations without complaint and reproach, even if they seem undeserved and unjust, seeing them as high calling. But a truly humble person can only be a committed Christian. He gives his destiny, body and soul into the hands of God and thus relies on his power and strength.

Having an idea of the hierarchy of values adopted by the tenet and making it their own internal imperative, people can, however, make an act contrary to his or her notion of due. But if it does, then it is already perceived by the subject as a sin in which he repents, while maintaining the priority of the inner imperative. It would not occur to him to boast or evaluate it as the norm, let alone to teach this to children. Thus, a religious moral imperative does not guarantee its violation but leaves the man in a consciously accepted value position. 
In morality, people's practical actions are evaluated as well as their motives, motives and intentions. In this regard, in moral regulation, the ability of the individual to define and direct his or her own behavior without daily external control is important. Hence the notion of morality, such as conscience, sense of personal dignity, honor - in secular morality, and correlation of their actions, thoughts, motives with the commandments given by God - in the religious.

Christianity proceeds from the understanding of value as an absolute good, possessing significance in every respect and for any subject. Christian values are not limited to the gospel commandments and moral rules. They make up the whole system.

The supreme blessing that is the source and all other values, for the Christian, is the God-revealed truth about the Holy Trinity as a perfectly perfect Spirit. Deity is not only absolute Reason and Almighty, but also perfect Grace and Love. This truth, confirmed by centuries of spiritual experience, constitutes, as if it were, the highest link in the hierarchy of Christian values, for it is the source of faith, which is the formative beginning of the Christian worldview. In the system of Christian values, the most important place is also given to the doctrine of the uniqueness of the human personality as an immortal, spiritual being created by God in His own image and likeness.

Christian teaching reveals the high sense and purpose of human life - bliss in the Kingdom of Heaven. The doctrine of salvation is also an essential part of the system of Christian values. In this way, the Word of God calls for complete, spiritual perfection. This is achieved through the joint action of Divine grace and free will. The value of the gospel beatitudes is determined by the fact that they are given to us by the Lord, as spiritual laws, the fulfillment of which brings us into eternal life.

Therefore, the effectiveness of a religious moral imperative is first and foremost an axiological aspect - the value not of God in itself, but of relations with God, the quality of those relations. The presence of a transcendental purpose is capable of transforming a man and, therefore, his actions. The axiological aspect of secular ethics is the value of the act itself. Secular ethics does not set the task of internal transformation, because it cannot provide this task with a worthy purpose and authority, thus providing role models but does not create a moral imperative in the exact meaning of the word. In addition, from the dawn of time human consciousness is initially dialogical. In case of a religious moral imperative, the man is in constant dialogue with God.

Christian values and, in particular, moral values are a great asset of humanity, but they become a blessed treasure only for those who go through salvation. The man makes the choice. "There is enough light for those who want to see, and enough darkness for those who do not want" (B. Pascal). 


\section{The moral religious imperative and the problem of the culture of coexistence}

One of the most acute and historically tragic problems of today is the problem of dialogue between civilizations and cultures. When it comes to such a dialogue in a global context, their qualitative differences are thereby recognized and it is about finding ways for their solidary, complementary existence in a single world. Such a dialogue is not possible without common principles that can only define the space of dialogue between them. They also refer to the relevance of the coexistence culture, which is characteristic of communities in which cultural, religious, linguistic, ethnic and political diversity coexist without antagonism, and the emergence of problems is based on equality and interaction. Coexistence as a way of personal and social being, a certain way of life and a lifestyle, is traced to relations of multisubject diversity, which are based on mutual trust, respect, recognition and related to social cohesion, socio-cultural integration and cooperation.

The coexistence culture poses to the modern world community the idea of a broad convergence of opposing systems through the gradual overcoming of conflicts and contradictions that arise on a political, economic, religious and ethnic basis; it involves cultural interaction that ultimately affirms the idea of freedom and positive change, the individuality of each through dialogue and trust, and helps to transform the perception and understanding of the "Alien" as the "Other".

First of all, let us note that the history of mankind is a dialogue that promotes the development of inter-ethnic, cross-national relations. But this process is complicated and not easy. Dialogue is the communication with culture, the realization and reproduction of its achievements, the identification and understanding of the values of other cultures, the way of appropriation of the latter, the possibility of relieving political tension between countries and ethnic groups. It is a necessary condition for the scientific search for the truth and the process of creativity in art. Dialogue is an understanding of one's "I" and communication with others.

The teachings of Martin Buber, a theological philosopher and interpreter of the Bible, are important to our study. For him the call "Adam, where are you?!" sounds both alarming and demanding. And the desire of a person to talk to God is combined with the task of listening to his call. M. Buber's central idea is being - as a dialogue between God and man, man and the world. Dialogue is salvatory when performed with the help of God, his commandments about morality and love. It is in this dialogue that the vitality of God Himself is revealed. The starting point of the concept of M. Buber is a dialogical principle. Man finds his own essence only by absorbing the humanity, while relating himself to other people. "Attitude toward man is a true resemblance to the attitude of God... Only in this sphere the word made in 
speech meets its answer... But only in the answer of God the revelation of everything is given, the revelation of all things as speech"3.

The contribution M. Buber made to the treasury of European civilization is determined by one important word: humanism. After the First World War, in the 1920's, when the man discovered that the development of reason does not bring along universal prosperity, but, quite often, on the contrary, increases the threat to the very human existence; when the dissolution of the people, expressed in the war, reached its highest point, the call to philanthropy, to a friendly and amorous attitude to oneself sounded very timely.

In this context, the religious paradigm of coexistence remains relevant in the general universe of coexistence culture for the three main reasons: anthropological and ontological requirements of human nature; a broad functional range of religion; the needs of the society to have a structure that would perform meaningful, legitimizing, integrating and nurturing functions.

In modern society of coexistence, the role of religious culture is growing precisely in connection with the crisis of civilization, which was primarily the result of the spiritual crisis. Religion cultivates a way of life that corresponds to the highest level of understanding of one's choice and responsibility to God for its consequences. Such a way of life and thinking opens itself in the context of the surrounding life as something attractive, as some real answer to the most pressing questions of human existence.

In the coexistence of people and communities, conflicts often arise on an interreligious basis. Racism, xenophobia, fanaticism and hatred have transformed the heart and mind of the modern individual into a potential battlefield. However, the sources of sectarian conflict and violence are not religious covenants, but their situational interpretation, misunderstanding between religious teachings, or manipulation with religious principles. It is the man who is the origin of any religious conflict that nullifies the postulates of coexistence culture, but it is in the act of moral choice that he can decide to choose God, love, good, truth, beauty and not hatred, evil, falsehood, ugliness.

Although interfaith and interreligious dialogue is gradually being recognized in Christianity as the norm, the attitude to tolerance and religious pluralism today is far from being straightforward. In addition to that, missionary activity in the classical sense of the term is understood as the acquisition of new members of the community, which today is impossible without dialogue and tolerance. Moreover, tolerance must be recognized as a value in an era of continuing ethnic and religious conflicts that cause violence. The goal of fostering tolerance is crucial not only for secular organizations, but also for religious and theological education.

\footnotetext{
${ }^{3}$ Бубер М. Я и Ты // Два образа веры. М.: Республика, 1995. - С. 47.
} 
In principle, the approach to the definition of tolerance, which is formulated in the UNESCO Declaration of Principles on Tolerance, can be taken as a basis: "Tolerance is harmony in difference... Tolerance, the virtue that makes peace possible, contributes to the replacement of the culture of war by a culture of peace" ${ }^{\prime 4}$. Here the criterion for the presence of tolerance is the visible result - overcoming tension, conflict, that is, tolerance must be expressed in one way or another in the activity. Thus, if the manifestation of Christian love bears fruit and leads to a peaceful resolution of conflicts, then one can speak of tolerance in the relations of the conflicting parties. At the same time, such an understanding of tolerance can serve missionary goals.

There is an obvious resource in Christian spirituality for cultivating tolerance - the belief that each person is created in the image and likeness of God, and the need for the testimony of Christian love. Faith itself immerses man in the space of love, for "God is love, and he who abides in love abides in God, and God in him" (1 John 4:16).

It stands to reason that the problem of tolerance is one of the most pressing problems of our time, and its religious aspect is just one of many. But, firstly, understanding this aspect allows us to reach the deep foundations of a conflict and secondly, it is this aspect that often plays a decisive role. The urgency of the problem of tolerance for the Ukrainian society is first and foremost related to the need to overcome its internal divisiveness including religious grounds. And the point is not only that modern Ukraine has both sectarian and interreligious tensions. The problem of lack of tolerance arises in the situation of conflicting interests of confessional communities but often within a monoconfessional religious association. When tolerance is understood as indifference, disregard to the matters of faith, then this understanding hides the ignorance of the origins of the humanistic worldview as well as spiritual essence of Christianity and its history.

The trends of the coexistence culture in the Ukrainian society over the last decade have been evidenced by a joint initiative of the Ukrainian Churches on the spiritual awakening and moral healing of the modern Ukrainian society, known as the "December $1^{\text {st }}$ Initiative" (Kyiv, December 2011). The spiritual and intellectual elite of Ukraine, represented by the initiative group of the First of December, composed of V. Bryukhovetsky, B. Havrylyshyn, S. Hluzman, V. Horbulin, Cardinal Lyubomir Huzar, I. Dziuba, M. Marynovych, M. Popovych, E. Sverstiuk, V. Skuratovsky, I. Yukhnovsky, appealed to the Ukrainians to overcome the social crisis, to change the situation in the country for the better in a peaceful way.

${ }^{4}$ UNESCO Declaration of Principles on Tolerance. - URL https://unesdoc.unesco.org/ ark:/48223/pf0000151830 
The main idea behind the activities of the Initiative Group is to consolidate the forces of the Churches and the State, community on the basis of coexistence, moral choice, responsibility, dialogue, compromise and reconciliation. This is evidenced, in particular, by the Group's Address "When the Joint Boat Turns Over - The Fault For This Will Lie on Everyone" (December 14, 2017), where, as a response to the civilizational challenges of today, it is stated: "The civilized world does not live by "arm-twisting" but by compromise - when, as a result of complex agreements, all parties are a somewhat dissatisfied, but the case is moving forward",.

Leading representatives of the Ukrainian intellectuals, most of whom became symbols of the unconquered Ukrainian spirit in the conditions of a totalitarian regime in the twentieth century, called on Ukrainians to find the strength to overcome common problems in a civilized way - in an act of moral choice that corresponds to the values of the religious moral imperative and the paradigm of the culture of coexistence.

Theoretical studies and practices of ethnic conflicts show that the culture of interethnic relations is extremely important for Ukraine and directly related to the effectiveness of the Christian moral imperative, which is part of the Christian value system. In the conditions of multireligiousness, the rapprochement of cultures of different denominations begins with political, civil dialogue between the church members. The experience of many countries shows that the diversity of religions and cultures in society is a sign of the healthy nation. However, only if the country has a true will of the nations and unrestricted prohibitions on the freedom of the individual. Poly-confessional culture is fruitful when it empowers the individual. Existing in a multi-denominational environment, based on their traditions and deep historical and cultural roots, Ukrainians will retain their ethnicity and develop themselves as a nation, enriching the culture of all existing denominations in the country which can contribute to its development.

\section{CONCLUSIONS}

The religious moral imperative is the basis of spiritual and practical life; the truth that is the center and the main idea of humanity. The religious moral imperative has a solid foundation in both essential and existential characteristics of culture, as both individuals and society as a whole seek to survive rather than self-destruct. The power of the religious moral imperative

\footnotetext{
5 Звернення Групи “Першого грудня": Коли спільний човен перекинеться - провина за це ляже на всіх. - URL: http://1-12.org.ua/2017/12/14/4067
} 
grows, having been supported in culture by its customs, state ideology, church and art. There is no function of religion that is not implemented in culture and is not supported in all its ways. This is because of the importance of one or another function for both the individual and society. The efficacy of a religious moral imperative is first and foremost an axiological aspect - the value not of God in itself, but of the relationship with God, the quality of those relationships. The presence of a transcendental purpose is capable of transforming a person, and therefore his actions.

The significance of a religious moral imperative lies in the effectiveness of overcoming the conflicting and destructive potential of intercultural relations, which is to translate these relationships from group form into interpersonal, when individually responsible thinking and behavior prevails.

The religious moral imperative permits moral work, opposition to sin, evil, and moral struggle. In the case of moral subjectivism, if even some moral norm is included in the personal moral complex, it is fulfilled only if it does not require any effort (or the very minimum). The difficulty of moral choice also lies in the fact that following it in one way or another requires certain efforts. But one of the peculiarities of the postmodernity man is that he has lost the habit of making moral efforts. This is possibly one of the causes of the crisis of spirituality in the modern world.

In our opinion, the whole complex of religious culture affirms values, the moral imperative of the humanistic worldview paradigm, activates the moral behavior of the subject. In this way, the philosophy of the culture of coexistence and its religious paradigm removes the secular and religious contradictions, which, in the appeal to the eternal values of personal and social existence, through moral choice, affirms the universal, eternal ideals of the truth, good and beauty.

We agree with M.M. Moiseev, who, on the eve of the $21^{\text {st }}$ century. wrote that "the formation of the moral imperative as a set of moral foundations of the life of a planetary society of the $21^{\text {st }}$ century is gradually growing into a major problem of modernity ... It is necessary to overcome the sediments of a two-thousand-year evolution and to learn to understand reality in all its nakedness, to learn to feel being included in the Universe. I think that the original doctrines of Christianity, combined with the original passionarity of Western culture that the ancient Greeks gave us, and with a reliance on collective intelligence, can play a crucial role in overcoming the inevitable crises of the coming century",

\footnotetext{
${ }^{6}$ Моисеев Н.Н. Мир XXI века и христианская традиция. - URL: http://www.ecolife.ru/ jornal/echo/2003-1-1.shtml
} 


\section{SUMMARY}

The article emphasizes that the moral imperative that preserves a religious tradition is the benchmark of the true path of the individual - as a truly free and personal. We affirm that mankind has not destroyed itself so far because there is an objective basis for its existence - the spiritual impulse of a religious tradition whose presence we find in culture and history. Following a religious moral imperative, the man is in a constant dialogue with God and is thus able to overcome the conflict-destroying vector of intercultural relations, the tendency of humanity to slip into an irreversible planetary catastrophe.

\section{REFERENCES}

1. Бодак В.А. Релігія і культура: взаємодія та взаємовплив : моногр. / В. А. Бодак. - К.; Дрогобич : Коло, 2005. - 306 с.

2. Бубер М. Я и Ты // Два образа веры. М.: Республика, 1995. C. $16-92$.

3. Булгаков C. Свет невечерний. Созерцания и умозрения. - URL: https://azbyka.ru/otechnik/6/svet-nevechernij-sozertsanija-i-umozrenija/

4. Гусейнов А., Апресян Р. Этика. - М.: Гардерики, 2003. - 472 с.

5. UNESCO Declaration of Principles on Tolerance. - URL: https://unesdoc.unesco.org/ark:/48223/pf0000151830

6. Звернення Групи "Першого грудня": Коли спільний човен перекинеться - провина за це ляже на всіх. - URL: http://1-12.org.ua/ 2017/12/14/4067

7. Мовчан В.С. Історія і теорія етики. - Дрогобич.: Коло, 2003. $512 \mathrm{c}$.

8. Моисеев Н.Н. Мир XXI века и христианская традиция. - URL: http://www.ecolife.ru/jornal/echo/2003-1-1.shtml

\section{Information about the author:}

Bodak V. A.,

Doctor of Philosophy Sciences, Professor at the Philosophy Department named after Valeriy Skotnyi, Drohobych Ivan Franko State Pedagogical University 24, Ivan Franko str., Drohobych, 82100, Ukraine 